\title{
White piedra and Trichosporon beigelii: the incidence in patients attending a clinic in genitourinary medicine
}

\author{
M WALZMAN,* J G LEEMING $†$ \\ From the Departments of Genitourinary Medicine, ${ }^{*}$ and Microbiology, $†$ General Hospital, Birmingham, UK
}

SUMMARY To assess the occurrence of white piedra and the asymptomatic carriage rate of $T$ beigelii, 100 heterosexual and 49 homosexual/bisexual men were entered into the study. White piedra of the scrotal hair was discovered in a total of four $(2.7 \%)$ patients (two heterosexual, one homosexual and one bisexual), while in addition a positive scrotal culture for $T$ beigelii was noted in a further seven $(4.8 \%)$ patients (four heterosexual and three homosexual). Rectal carriage rates were $1 \%$ in the heterosexual and $4 \%$ in the homosexual/bisexual groups, while there was no pharyngeal carriage in either group.

Trichosporon beigelii is a yeastlike fungus, which causes an unusual sporadic condition known as white piedra. This condition occurs in both temperate and tropical climates' and is characterised by numerous, discrete, soft white or light brown nodules attached to infected hair shafts. ${ }^{2}$ Although white piedra may involve the hairs of the scalp, moustache, beard, eyelashes, eyebrows, axilla or groin, there have been many reports of it being confined to the pubic and scrotal regions. ${ }^{3-8} T$ beigelii has also been reported in monkeys, horses and domestic animals. ${ }^{356}$

In the past, this fungus was considered to only cause a relatively innocuous superficial infection. Increasing numbers of reports have now revealed, however, the potential of $T$ beigelii to act as an opportunistic pathogen, causing serious invasive and life-threatening disease, mainly in immunosuppressed patients. ${ }^{9-20}$

Recent studies from Scandinavia have demonstrated anal carriage rates of $T$ beigelii in the range of 13 to $15 \%$ in groups of homosexual men. ${ }^{21}{ }^{22}$ A study from the United States revealed a high carriage rate of $T$ beigelii, from cultures of scrotal hairs of patients attending a City Health Sexually Transmitted Diseases Clinic. ${ }^{23}$

The purpose of this study was to assess the incidence of white piedra and the carriage rate of $T$ beigelii in male patients (heterosexual and homosexual), attending a clinic of genitourinary medicine in the United Kingdom.

Address for reprint requests: Dr M Walzman, Coventry and Warwickshire Hospital, Stoney Stanton Road, Coventry CV1 4FH, UK.

Accepted for publication 25 June 1989

\section{Patients and methods}

Following verbal consent, 100 heterosexual and 49 homosexual/bisexual men (41 homosexual and eight bisexual), who attended the clinic of genitourinary medicine at the General Hospital, Birmingham, were entered into this study. The standard clinic history was taken and examination and screening for the usual sexually transmitted conditions were performed on all patients. Additional information in the form of recent travel abroad and the keeping of domestic pets (cats, dogs and birds) was obtained. The patients' scrotal hairs were examined for the presence of nodules and samples of this hair were taken for microscopy and culture.

A $20 \%$ potassium hydroxide mount of a scrotal hair was viewed under the microscope to demonstrate the characteristic nodules, located at varying intervals along the hair shaft (fig). Under higher magnification the arthrospores in these nodules were visible.

A scrotal impression smear (achieved by allowing the scrotum to rest firmly on a malt agar plate) was taken, as were rectal and pharyngeal specimens using cotton swabs. Cultures (of scrotal hair, scrotal impression, rectal and pharyngeal specimens) were grown at $25^{\circ} \mathrm{C}$ on malt extract agar plates (Oxoid Ltd), with added chloramphenicol $(50 \mu \mathrm{g} / \mathrm{ml})$. Cultures were incubated for up to two weeks. ${ }^{22} \mathrm{~T}$ beigelii appeared as creamy coloured yeastlike colonies, which became heaped and wrinkled.

Microscopic growth was composed of branched mycelium that fragments into arthrospores. This was demonstrated by streaking the organism across the surface of a corn meal agar plate (Oxoid Ltd), covered 


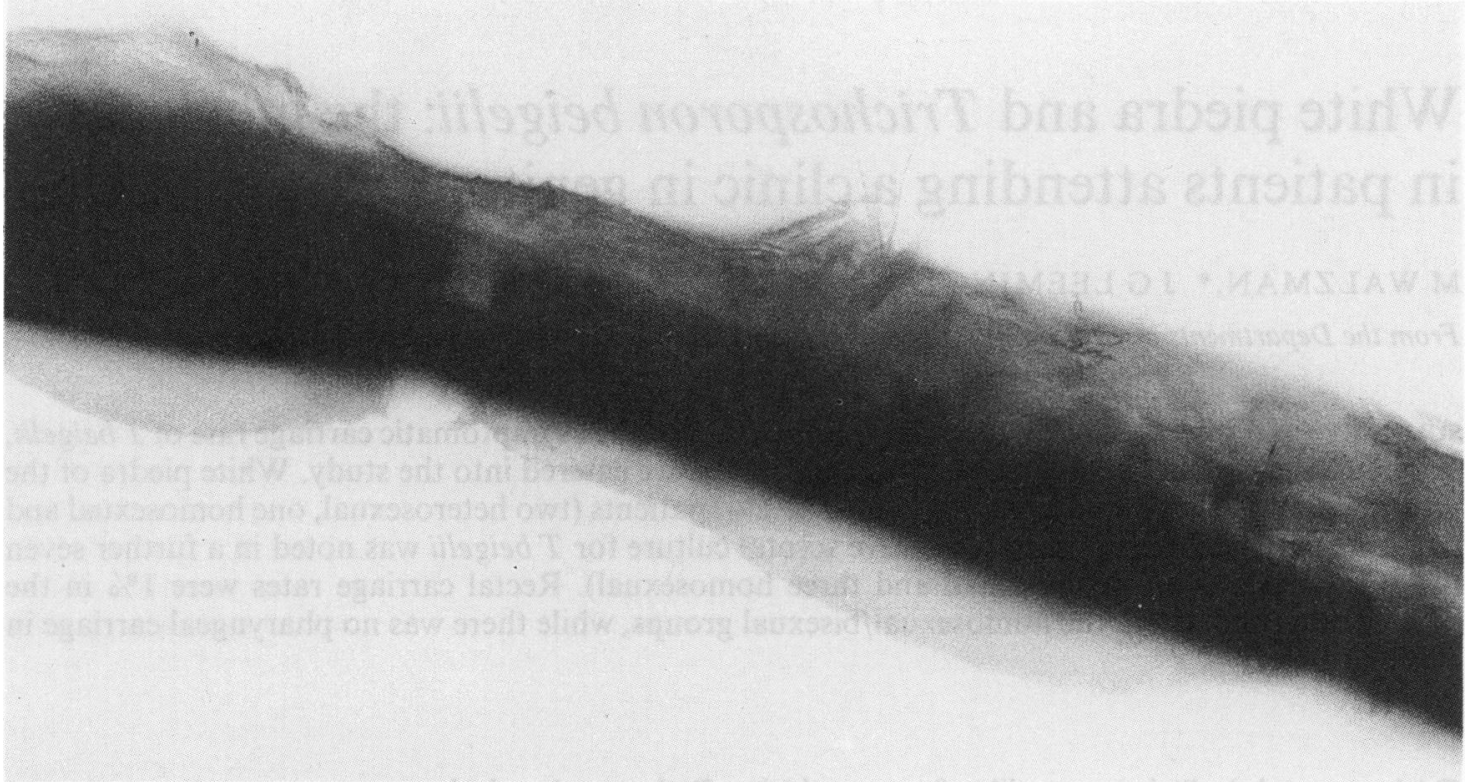

Figure Scrotal hair under low-power microscope demonstrating adherent nodules (potassium hydroxide, original magnification $\times 100)$.

with a sterile coverslip and incubated at $25^{\circ} \mathrm{C}$ for three days. The growth was observed by viewing the plate under a microscope (magnification $\times 100$ ).

Further identification of $T$ beigelii based on biochemical characteristics was also made on the basis of assimilation tests using the API $20 \mathrm{C}$ system. All of the strains isolated assimilated glucose, 2-keto-D-gluconate, D-xylose, galactose, inositol, $\alpha$ methyl-Dglucoside, $\mathrm{N}$ acetyl-D-glucosamine, cellobiose, lactose, maltose, sucrose, trehalose and melezitose, and all produced urease.

\section{Statistical analysis}

The $\chi^{2}$ test was used to analyse the relationship between travel abroad and pet ownership to having a positive culture for $T$ beigelii.

\section{Results}

Eleven $(7 \cdot 4 \%)$ of the patients had a positive culture for
$T$ beigelii, six (6\%) of the heterosexual and five $(10 \cdot 2 \%)$ of the homosexual/bisexual group. Of these 11 patients, eight $(72.7 \%)$ gave a history of recent travel abroad and five $(45.4 \%)$ owned pets, while of the 138 who were culture negative, $74(53.6 \%)$ had travelled abroad and $65(47 \%)$ owned pets. Analysis of these results revealed no significant difference between those with positive and negative cultures who either travelled abroad $\left(\chi^{2}=0.8297 ; p=0.6345\right)$, or owned domestic pets $\left(\chi^{2}=0.0435 ; \mathrm{p}=0.8295\right)$.

The sites of isolation of $T$ beigelii are shown in the table. Four patients (two from each group) had white piedra of their scrotal hair and although the nodules were visible on close scrutiny, all patients were asymptomatic. One of these patients, however, on questioning, did notice that the hairs broke easily. Two further patients had a positive culture from the scrotal hair but without macro or microscopic evidence of nodules. All patients were positive for $T$ beigelii from the scrotal impression plates, and in three of these (two homo-

Table Occurrence of white piedra and the growth of $T$ beigelii from scrotal, rectal and pharyngeal regions of six heterosexual and five homo/bisexual men

\begin{tabular}{llllll}
\hline & Number & $\begin{array}{l}\text { Nodules on } \\
\text { scrotal hair } \\
\text { (white piedra) }\end{array}$ & $\begin{array}{l}\text { Growth of } \\
\text { Theigelli } \\
\text { from scrotal } \\
\text { hair }\end{array}$ & $\begin{array}{l}\text { Growth of } \\
\text { Theigelii } \\
\text { from scrotal } \\
\text { impression plate }\end{array}$ & $\begin{array}{l}\text { Growth of } \\
\text { T beigelii } \\
\text { from rectal } \\
\text { culture }\end{array}$ \\
\hline $\begin{array}{l}\text { Heterosexual men } \\
\text { Homosexual/ } \\
\text { bisexual men }\end{array}$ & 6 & 2 & 4 & 6 & $\begin{array}{l}\text { Growth of } \\
\text { from pharyngeal } \\
\text { culture }\end{array}$ \\
\hline
\end{tabular}


sexual and one heterosexual), $T$ beigelii was also cultured from their rectal swabs. In all these cases the patients were asymptomatic and there were no obvious signs.

\section{Treatment and outcome}

Treatment of patients with white piedra was in two cases by clipping the scrotal hairs and the twice daily application of clotrimazole $1 \%$ in one case and econazole nitrate $1 \%$ in the other. One of the other cases was prescribed econazole nitrate $1 \%$ only, while the fourth patient failed to return for follow-up. Of the three patients who received treatment, only one returned, this patient having clipped the scrotal hairs and applied econazole nitrate $1 \%$. The white piedra had disappeared but the scrotal impression plate remained positive for $T$ beigelii.

\section{Discussion}

There has been an increasing number of reports of white piedra affecting the genito-pubic region ${ }^{3-823}$ and it has been suggested that this appears as a separate clinical entity, whereby the genital and pubic hairs are affected at the exclusion of all other hairy regions. ${ }^{8}$ This condition has been found in both male and female patients. ${ }^{23}$ The possibility of person to person transmission of $T$ beigelii has been suggested ${ }^{4}$ although this appears to be a rare occurrence. ${ }^{23}$ The finding of $T$ beigelii in rectal specimens from homosexuals, ${ }^{2122}$ however, lends to the possibility of a sexual mode of transmission in this group of patients.

Since $T$ beigelii was first reported as causing a brain abscess in a patient with a bronchial carcinoma,${ }^{10}$ there have been an increasing number of reports of it being responsible for serious systemic infection in patients immunocompromised as a result of malignancies or bone marrow transplant. ${ }^{11-20}$ The diagnosis in systemic infection may be difficult, especially since it is probably not often sought after, or may be regarded as a contaminant and overlooked when found, ${ }^{1218}$ and may even be incorrectly identified as candida or aspergillus. ${ }^{1718}$ The portal of entry of $T$ beigelii in cases of disseminated infection is unclear; however, enteric, respiratory and cutaneous origins have been suggested. ${ }^{16}$ The finding therefore, of a relatively high carriage rate (cutaneous and rectal) of $T$ beigelii in our study and others where patients attending STD clinics have been screened for this fungus, ${ }^{21-23}$ could be of clinical importance if $T$ beigelii was discovered to act as an opportunistic pathogen, when patients become immunosuppressed as a consequence of HIV infection.

There has, however, to date been no report of $T$ beigelii infection amongst patients suffering from the acquired immune deficiency syndrome (AIDS). This may be due to a lack of recognition of this pathogen, or as suggested by Lowenthal et al,,$^{20}$ may be either a matter of time, or the immunosuppression in AIDS does not predispose to $T$ beigelii infection, in a manner similar to those who are immunocompromised as a result of malignancy or bone marrow transplantation. Time and further studies may resolve whether or not $T$ beigelii and white piedra have any clinical significance as regards possible opportunistic infection amongst patients infected with HIV.

Travel outside the United States was considered to be a predisposing factor in $T$ beigelii colonisation in one report, ${ }^{5}$ however, a recent large study failed to confirm this observation. ${ }^{23}$ Similarly, we found no relationship to travel outside the United Kingdom and $T$ beigelii isolation. Although $T$ beigelii has been reported in domestic animals, ${ }^{356}$ our study suggests that this is an unlikely source of transmission to humans.

As in this study, white piedra is often asymptomatic, ${ }^{8}$ and we have demonstrated in agreement with others, ${ }^{3823}$ that it is a much more common condition than originally appreciated. We suggest that a closer examination, especially if aided with a magnifying glass, would reveal more cases. Like Kalter et $a l,{ }^{23}$ we found follow-up for treatment and repeat culture difficult in this group of patients. A common finding is that eradication of the fungus is generally unsuccessful, independent of whichever treatment regimen is used. ${ }^{523}$ Patient lack of compliance with instructions and reinfection are possible contributory factors to treatment failure: a further theory is that the fungus dwells in both intra and extrafollicular portions of the hair shaft, making local treatments inadequate, since they do not reach the intrafollicular nidus. ${ }^{23}$

Considering the above difficulties in the treatment of $T$ beigelii and the often asymptomatic nature of genito-pubic white piedra, one could easily question the merits of seeking out and attempting to treat this condition. Until its totally inocuous nature is confirmed, however, we feel that treatment in the form of shaving the hair is justified, especially in high risk patient groups.

Finally, since white piedra may be confused with pediculosis clinically, a knowledge of the formers existence is useful in the differential diagnosis of the latter condition.

We are grateful to Dr M Shahmanesh for his assistance with this study.

\section{References}

1 Conant NF, Tillerson D, Baker RD, Callaway JL, Martin DS. Piedra. In: Conant NF, Tillerson D, Baker RD, Callaway JL, Martin DS, eds. Manual of clinical mycology. Philadelphia and London: W B Saunders Company, 1963:353-8. 
2 Roberts SOB, Hay RJ, MacKenzie DWR. The Superficial Mycoses: Tropical Superficial Infections. In: Roberts SOB, Hay RJ, MacKenzie DWR, eds. A clinicians guide to fungal disease. New York, Basel: Marcel Dekker Inc, 1984:92-4.

3 Smith JD, Murtishaw WA, McBride ME. White Piedra (Trichosporosis). Arch Dermatol 1973;107:439-42.

4 Lassus A, Kanerva L, Stubb S, Salonen A. White Piedra. Report of a case evaluated by scanning electron microscopy. Arch Dermatol 1982;118:208-11.

5 Benson PM, Lapins NA, Odom RB. White Piedra. Arch Dermatol 1983;119:602-4.

6 Steinman HK, Pappenfort RB. White Piedra - a case report and review of the literature. Clin Exp Dermatol 1984;9:591-8.

7 Fishman HC. White Piedra. Int J Dermatol 1987;26:538.

8 Avram A, Buot G, Binet O, Gracia AM, Cesarini JP. Etude Clinique et Mycologique concernant 11 cas de Trichosporie noueuse (piedra blanche) génito-pubienne. Ann Dermatol Venereol 1987:114:819-27.

9 Warnock DW. Unusual fungal infections in the compromised patient. In: Warnock DW, Richardson MD, eds. Fungal infection in the compromised patient. Chichester: John Wiley and Sons Ltd, 1982:217-28.

10 Watson KC, Kallichurum S. Brain abscess due to Trichosporon cutaneum. J Med Microbiol 1970;3:191-3.

11 Rivera R, Cangir A. Trichosporon sepsis and leukaemia. Cancer 1975;36:1106-10.

12 Kirmani N, Tuazon CU, Geelhoed GW. Disseminated Trichosporon Infection: Occurrence in an immunosuppressed patient with chronic active hepatitis. Arch Intern Med 1980;140:277-8.

13 Evans HL, Kletzel M, Lawson RD, Frankel LS, Hopfer RL. Systemic mycosis due to Trichosporon cutaneum. A report of two additional cases. Cancer 1980;45:367-71.
14 Yung CW, Hanauer SB, Fretzin D, Rippon JW, Shapiro C, Gonzalez M. Disseminated Trichosporon beigelii (cutaneum) Cancer 1981;48:2107-11.

15 Manzella JP, Berman IJ, Kukrika MD. Trichosporon beigelii fungemia and cutaneous dissemination. Arch Dermatol 1982;118:343-5.

16 Haupt HM, Merz WG, Beschorner WE, Vaughan WP, Saral R. Colonization and infection with Trichosporon species in the immunosuppressed host. J Infect Dis 1983;147:199-203.

17 Libertin CR, Davies NJ, Halper J, Edson RS, Roberts GD. Invasive Disease caused by Trichosporon beigelii. Mayo Clin Proc 1983;58:684-6.

18 El-ani AS, Castillo NB. Disseminated infection with Trichosporon beigelii. NY State J Med 1984;84:457-8.

19 Dreizen S, McCredie KB, Bodey GP, Keating MJ. Unusual mucocutaneous infections in immunosuppressed patients with leukemia - expansion of an earlier study. Post Grad Med 1986;79:287-94.

20 Lowenthal RM, Atkinson K, Challis DR, Tucker RG, Biggs JC. Invasive Trichosporon cutaneum infection: an increasing problem in immunosuppressed patients. Bone Marrow Transplant 1987;2:321-7.

21 Torssander J, Carlsson B, Von Krogh G. Trichosporon beigelii: Increased occurrence in homosexual men. Mykosen 1985;28:355-6.

22 Stenderup A, Schønheyder H, Ebbesen P, Melbye M. White piedra and Trichosporon beigelii carriage in homosexual men. $J$ Med Vet Mycol 1986;24:401-6.

23 Kalter DC, Tschen JA, Cernoch PL, McBride ME, Sperber J, Bruce S, Wolf JE Jr. Genital white piedra: Epidemiology, microbiology and therapy. J Am Acad Dermatol 1986;14 982-93. 